\title{
Onafhankelijkheid van ondernemingstoezicht
}

\author{
Prof. Dr: P.W. Moerland
}

\section{Inleiding}

Vrijwel overal ter wereld wordt het belang van een onafhankelijk toezicht op het ondernemingsbestuur benadrukt. Commissarissen hebben tot taak toezicht te houden op het beleid van het ondernemingsbestuur en op de algemene gang van zaken in de vennootschap. Een adequate vervulling van die taak vereist aan de ene kant een grote mate van betrokkenheid bij het reilen en zeilen van de onderneming om tot een verantwoorde oordeelsvorming te komen. Aan de andere kant dient een zekere distantie in acht te worden genomen teneinde een verstrengeling van bestuur en toezicht te vermijden. Pleitbezorgers voor een goede corporate governance wijzen in het algemeen op dit gevaar van belangenvermenging. Amerikaanse instanties bepleiten een forse meerderheid van het aantal onafhankelijke outsiders in de board of directors'. Amerikaanse institutionele beleggers zijn beducht voor externe hoard-leden die banden hebben met het management als gevolg van familierelaties, adviescontracten of kruislingse posities $^{2}$. De Britse Cadbury Commissie (1992) beschouwt onafhankelijkheid van de hoard of directors als een vitaal clement van best practice in corporate governance. In de aanbevelingen van deze invloedrijke Commissie is dit als volgt verwoord: 'Non-executive directors should bring an independent judgement to bear on issues of strategy, performance, resources, including key appointments, and standards of conduct'. En verder: 'The majority should be independent of management and free from any business or other relationship which could materially interfere with the exercise of their independent judgement, apart from their fees and sharcholding".

Prof. Dr. P.W. Moerland is hoogleraar Ondernemingsfinanciering en Corporate Governance aan de Katholieke Universiteit Brabant te Tilburg.
Ook de OECD onderstreept het belang van onafhankelijk toezicht, getuige het volgende citaat uit een door haar opgestelde gedragscode (1999): 'Board independence usually requires that a sufficient number of board members not be employed by the company and not be closely related to the company or its management through significant economic, family or other ties. Independent board members can contribute significantly to the decision making of the board. They can bring an objective view to the evaluation of the performance of the board and management. In addition, they can play an important role in areas where the interests of management, the company and shareholders may diverge (...).'

Voor ons eigen vennootschappelijke bestel heeft de Commissie Corporate Governance (1997), beter bekend als de Commissie-Peters een relatief groot antal van de in totaal veertig aanbevelingen gedaan waarin het aspect onafhankelijkheid expliciet (de aanbevelingen 2, 5 en 10) dan wel impliciet (de aanbevelingen 4, 7, 8, 12, 13 en $20)$ aan de orde is. De tekst van deze aanbevelingen is in de bijlage opgenomen.

In Nederland wordt, anders dan in de Angelsaksische landen, evenwel een tweetal verschillende typen van onafhankelijkheid onderscheiden, te weten:

onafhankelijkheid van hen over wie het toezicht wordt uitgeoefend (het ondernemingsbestuur);

onafhankelijkheid van hen namens wie het toezicht wordt uitgeoefend (de stakeholders).

Het eerste type onafhankelijkheid is verwant aan hetgeen door Cadbury en de OECD wordt beoogd. Het tweede type onafhankelijkheid is een specifiek Nederlandse aangelegenheid.

Dit artikel is gewijd aan een analyse en evaluatie van het aspect onafhankelijkheid van het toezicht binnen ondernemingen. We richten ons daarbij op 
het toezicht, zoals dat wettelijk is toebedeeld aan een toezichthoudend orgaan, zoals de Raad van Commissarissen in Nederland en de board of directors in de Angelsaksische landen. De taak van een dergelijk orgaan is om de directie te adviseren en om toezicht uit te oefenen op de wijze waarop de directie invulling geeft aan het ondernemingsbeleid. Naast het toezicht bestaan er andere vormen van disciplinering van het ondernemingsbestuur. zoals door grootaandeelhouders. externe instanties, zoals de Stichting Toezicht Effectenverkeer, en dergelijke. In deze bijdrage houden we ons alleen bezig met het ondememingstoezicht door middel van een daartoe bedoeld vennootschappelijk orgaan. Er bestaan belangrijke internationale verschillen ten aanzien van de wijze waarop het toezicht wettelijk is geregeld en praktisch gestalte krijgt, en wel wat betreft de structuur van het toezicht, de samenstelling van het toezichthoudend orgaan, het voordracht- en benoemingsrecht ten aanzien van leden van het toezichthoudend orgaan, en de taakstelling en oriëntatie van het toezicht.

In paragraaf 2 wordt een internationale vergelijking getroffen van de uiteenlopende systemen van ondernemingstoezicht.

In paragraaf 3 wordt het Nederlandse systeem van ondernemingstoezicht, meer in het bijzonder het structuurregime, beschreven. Herkomst. kenmerken en de onderlinge samenhang met andere aspecten van corporate governance komen aan bod.

Paragraaf 4 bevat cen evaluatie van de onafhankelijkheid binnen het Nederlandse systeem in vergelijking met die in andere landen. Daarbij wordt ingegaan op beide typen onafhankelijkheid. dat wil zeggen van toezichthouders ten opzichte van het ondernemingsbestuur (en directie) en ten opzichte van de stakeholders.

In deze bijdrage komen dus een tweetal deelvragen van het aspect onafhankelijkheid aan bod. Ten eerste de vraag hoe het Nederlandse regime zich in dat opzicht verhoudt tot het internationale spectrum. Ten tweede de vraag of en in welke mate onathankelijkheid van het toezicht ten opzichte van de directic effect heeft op de financiële prestaties van ondernemingen, met name in de Verenigde Staten.

Paragraaf 6 besluit met enkele conclusies en kanttekeningen.

\section{Internationale vergelijking van toezichthou- dende systemen}

Er bestaan aanmerkelijke verschillen in toezichthoudende regimes, in het bijzonder voor wat betreft de volgende aspecten: structuur van het toezicht:

samenstelling van het toezichthoudend orgaan; voordracht- en benoemingsrecht betreffende de leden;

taakstelling en oriëntatie van het toezicht.

Deze aspecten worden hicrna verder toegelicht.

\section{Structulur}

Gewoonlijk wordt een onderscheid gemaakt tussen een one-tier en two-tier structuur van toezicht. Bij een one-tier structuur hebben zowel interne managers als externe leden zitting in het toezichthoudend orgaan. Allen hebben gelijke verantwoordelijkheden en aansprakelijkheden. Een twotier structuur voorziet in een formele scheiding tussen het toezichthoudend orgaan en het bestuursorgaan. Het toezichthoudend orgaan bestaat alleen uit externe leden.

De meeste landen, zoals de Verenigde Staten. het Verenigd Koninkrijk, en de Latijns-Europese landen, kennen de one-fier structuur-'. In onder andere Duitsland en Nederland wordt gewerkt met de two-tier structuur.

\section{Sumenstelling}

Samenstelling en structuur hangen met elkaar samen. Bij een one-tier structuur omvat het toezichthoudend orgaan zowel insiders (executive managers) als outsiders (non-executive buitenstaanders), terwijl bij een (w'o-tier structuur alleen outsiders zitting nemen in het toezichthoudend orgaan. Voor de one-fier structuur is het onderscheid tussen insiders en outsiders niet geheel toereikend. Baysinger en Butler (1985) maken een onderscheid tussen insiders, geaffilieerde outsiders en waarlijk onafhankelijke outsiders.

Belgische toczichtsorganen (aldaar Raad van Bestuur genoemd) huisvesten gewoonlijk ondernemingsbestuurders, vertegenwoordigers van referentic-aandeelhouders, en onafhankelijke externen. De regimes voor two-fier structuren verschillen van land tot land. Zo zijn bij grote Duitse vennootschappen de zetels van het toezichthoudend orgaan (Aufsichtsrut) gelijkelijk verdeeld over vertegenwoordigers van de aandeelhouders en vertegenwoordigers van de werknemers. In Nederland kennen we een dergelijke segmentering nict. maar de wet vereist dat de Raad van Commissarissen naar behoren is samengesteld. hetgeen kan worden opgevat als een evenwichtige samenstelling, welke een voldoende breed spectrum van relevante expertise en oriëntatie wcerspiegelt.

\section{Voordracht en benoeming}

Bij de one-fier structuur berust het benoemingsrecht in het algemeen bij de aandeelhouders. In 
Amerikaanse en Britse vennootschappen is veelal een nominating committee binnen de board werkzaam die zich bezighoudt met het opstellen van een voordracht.

In het Duitse systeem worden leden van het toezichthoudend orgaan benoemd, op fifty-fifty basis, door de aandeelhouders en door werknemersorganen (ondernemingsraden en vakbonden). De voorzitter kont evenwel van de zijde van de aandeelhouders. Zijn stem is, ingeval van een impasse, doorslaggevend. Onder het Nederlandse structuurregime worden de leden van de Raad van Commissarissen benoemd door de Raad zelve. De Algemene Vergadering van Aandeelhouders, de Ondernemingsraad en het Bestuur mogen kandidaten aanbevelen, maar het is de Raad van Commissarissen die benoemt. Deze Raad benoemt tevens de leden van de Raad van Bestuur. De Algemene Vergadering van Aandeclhouders en de Ondernemingsraad zijn gerechtigd om bezwaar aan te tekenen tegen voorgenomen benoemingen tot commissaris. Onder het gewone regime worden leden van de Raad van Commissarissen en van de Raad van Bestuur in beginsel benoemd door de Algemene Vergadering van Aandeelhouders. Houders van prioriteitsalandelen beschikken veelal over het recht om een bindende voordracht uit te brengen, welke overigens door de Algemene Vergadering van Aandeelhouders ongedaan kan worden gemaakt door middel van een gekwalificeerd meerderheidsbesluit.

\section{Oriëntatie}

Er bestaan internationale verschillen in de oriëntatie op het type belangen waarnaar men zich bij de uitoefening van het toezicht heeft te richten. In de Anglo-Amerikaanse en Latijns-Europese landen wordt de beursvennootschap traditioneel beschouwd als een instrument ten behoeve van het aandeelhoudersbelang. Vooral in de LatijnsEuropese landen zijn kernaandeelhouders veelal vertegenwoordigd in het toezichthoudend orgaan, en zij zijn daardoor in de gelegenheid om het ondernemingsbeleid rechtstreeks te beïnvloeden. mede in het belang van henzelf.

In landen als Duitsland en Nederland is de oriëntatie van toezichthouders veeleer gericht op het totale belang van de onderneming. In ons land bestaat hiertoe een zelfs wettelijke verplichting.

\section{Het Nederlandse systeem van toezicht}

Nederland kent een uniek systeem voor de uitoefening van toezicht in ondernemingen, zeker waar het de structuurvennootschap betreft. Dit kwam bij de in paragraaf 2 beschreven internationale vergelijking al enigszins naar voren. Het struc- tuurregime is wettelijk van toepassing als gedurende drie aaneengesloten jaren aan de volgende drie eisen cumulatief is voldaan ${ }^{4}$ :

het geplaatste kapitaal van de vennootschap bedraagt minimalal 25 miljoen gulden; de vennootschap heeft krachtens wettelijke verplichting cen Ondernemingsraad ingesteld; bij de vennootschap zijn ten minste 100 werknemers in Nederland werkzaam.

Indien aan deze voorwaarden is voldaan geldt toepassing van het structuurregime als verplichting. Het is ook mogelijk dat een vennootschap op vrijwillige basis het structuurregime in haar statuten opneemt. Er moet dan wel een verplichte Ondernemingsraad zijn. Voorts is een aantal situaties in de wet geregeld waarin het structuurregime wordt uitgesloten of beperkt wordt toegepast.

Uitgesloten zijn ondergeschikte maatschappijen waarvan het structuurregime op de topholding van toepassing is. Daarnaast zijn service/financieringsmaatschappijen en holdings van multinationals uitgesloten indien het overgrote deel van het personeel van de vennootschap in het buitenland werkzaam is. De Nederlandse Ondernemingsraad is dan niet voldoende representatief voor het concern. Een beperkte toepassing is aan de orde bij dochtermaatschappijen van internationale concerns, waarvan de werknemers tezamen met die van de andere concermmatschappijen hoofdzakelijk in het buitenland werkzaam zijn.

Kenmerk van het structuurregime is de verplichte benoeming van een Raad van Commissarissen. Deze Raad benoemt haar leden zelf, het zogenoemde coöptatie-systeem. De Algemene Vergadering, de Ondernemingsraad en het Bestuur beschikken over een aanbevelingsrecht, maar dit is nict bindend van karakter.

De Raad van Commissarissen heeft onder het structuurregime een aantal sleutelbevoegdheden: benoeming en ontslag van bestuurders; vaststelling van de jaarrekening; goedkeuring van een aantal ingrijpende bestuursbesluiten.

Bij het beperkte structuurregime zijn de eerste twee sleutelbevoegdheden niet van toepassing.

Daarnaast kennen we in ons land het gewone regime van toezicht. Dit regime berust niet op een wettelijke verplichting, maar staat ter vrije keuze van vennootschappen die niet onder het verplichte structuurregime vallen. Die vennootschappen mogen een Riad van Commissarissen instellen, waarvan de leden in beginsel worden benoemd door de Algemene Vergadering van Aandeelhouders. 
Het structuurregime dateert van 1971, en staat bekend als het 'wonder van Den Haag'. De Commissie-Verdam overwoog, in de jaren zestig van de vorige eeuw, dat participatie door werknemers in de besluitvorming van de onderneming mede tot uitdrukking moest komen in de wijze waarop het toezicht is geregeld. Daar kwam bij dat het absenteïsme op vergaderingen van aandeelhouders geleidelijk aan was toegenomen door verdere verspreiding van het aandelenbezit. Dat hield het gevaar in van toevallig wisselende meerderheden in die vergaderingen, hetgeen de continuiteit van de besluitvorming niet ten goede zou komen. Bovendien zou de ondernemingsleiding onvoldoende tegenspel krijgen van een minder gocd functionerende aandeelhoudersvergadering. Daarom werd door de Commissie-Verdam geadviseerd om een krachtig toczichthoudend orgalan in het leven te roepen, dat tegenwicht zou kunnen bieden aan het ondernemingsbestuur. De

Commissie was evenwel niet bij machte om unani- miteit te bereiken over het benocmingsrecht van commissarissen. Binnen de Commissie gingen stemmen op om vertegenwoordigers van werknemers op te nemen in de Raad van Commissarissen, een gedachte waar anderen het mee oneens waren. Het was de Sociaal Economische Raad die in 1969 adviseerde om een gecontroleerd systeem van coöptatie in te voeren, waarbij de Raad zijn eigen leden benoemt, maar waarbij aandeelhouders en werknemers gelijke rechten zouden worden tocbedeeld voor het doen van aanbevelingen en het maken van bezwaar. Aldus geschiedde het eerdergenoemde 'wonder van Den Haag'. Saillant is dat het fenomeen van de werknemerscommissaris thans weer op de publieke agenda staat en dat de Sociaal Economische Raad zich opnicuw buigt over het structuurregime.

In 1998 verscheen het Monitoring-rapport van de Monitoring-commissie. Daarin worden voor 150 binnenlandse beursvennootschappen (exclusief

Tabel 1: Samenhang fussen het type vennootschap en de aanwerigheid van grootaandeelhouders (samengesteld op basis van gegevens vermeld in het Monitoring-rapport 1998)

\begin{tabular}{|c|c|c|c|c|c|c|}
\hline & \multicolumn{4}{|c|}{ structumeriennootschap } & \multirow{3}{*}{$\begin{array}{l}\text { met-structutir- } \\
\text { bennootschap }\end{array}$} & \\
\hline & \multicolumn{2}{|c|}{ rerplicht } & \multirow[t]{2}{*}{ mijuillig } & \multirow[t]{2}{*}{ rotaal } & & \\
\hline & rolledig & bepertit & & & & \\
\hline $\begin{array}{l}\text { meerderheids- } \\
\text { aandeelhouder } \\
(>50 \%)\end{array}$ & $5\left(8^{0} \%\right)$ & $4(67 \%)$ & $4(16 \%)$ & $13(13 \%)$ & $18(29 \%)$ & $31(19 \%)$ \\
\hline \multirow{2}{*}{$\begin{array}{l}\text { geen meerderheids- } \\
\text { aandeelhouder }\end{array}$} & $61(92 \%)$ & $2(33 \%)$ & $21\left(84^{\%} \%\right)$ & $84(87 \%)$ & $44(71 \%)$ & $128(81 \%)$ \\
\hline & $66(100 \%)$ & $6(100 \%)$ & $25(100 \%)$ & $97(100 \%)$ & $62(100 \%)$ & $159(100 \%)$ \\
\hline $\begin{array}{l}\text { grootaandeel- } \\
\text { houder }(>25 \% \text { is) }\end{array}$ & $20(30 \%)$ & $6(100 \%)$ & $11(44 \%)$ & $37(38 \%)$ & $3(0(48 \%)$ & $67(42 \%)$ \\
\hline \multirow{2}{*}{$\begin{array}{l}\text { geen } \\
\text { grootaandecthouder }\end{array}$} & $46(70 \%)$ & $0(0 \%)$ & $14(56 \%)$ & $60(62 \%)$ & $32(52 \%)$ & $92(58 \%)$ \\
\hline & $66(100 \%)$ & $6(100 \%)$ & $25(100 \%)$ & $97(100 \%)$ & $62(100 \%)$ & $159(100 \%)$ \\
\hline
\end{tabular}


beleggingsfondsen) de resultaten van een monitoringproces weergegeven aangaande de male waarin en de wijze waarop die ondernemingen de aanbevelingen van de eerste Commissic-Peters hebben overgenomen. Dat rapport bevat tevens interessante informatic over de zeggenschapskenmerken van de desbetreffende vennootschappen.

Van de groep van 159 vennootschappen vallen er $97(61 \%)$ onder het structuurregime: $72(45 \%)$ verplicht (waarvan 66 volledig regime en 6 beperkt regime), en 25 ( $16 \%$ ) op vrijwillige basis. $41(26 \%)$ vennootschappen kennen prioriteitsaandelen, $56(35 \%)$ certificaten, en $88(55 \%)$ hebben beschermingspreferente aandelen. Slechts enkele ondernemingen kennen stemrechtbeperking van de gewone aandelen.

Van de 159 onderzochte vennootschappen beschikken er 31 (19\%) over een meerderheidsaandeelhouder, terwijl $67(42 \%)$ vennootschappen over een aandeelhouder beschikken die een belang heeft van meer dan een kwart.

Tabel 1 (zie pag. 327) brengt de samenhang in beeld tussen het type vennootschap (al dan niet structuurvennootschap) en de aanwezigheid van grootaandeelhouders (meerderheidsaandeelhouder of aandeelhouder met belang groter dan een kwart).

Uit tabel 1 kan worden afgeleid, dat: de relatieve frequentie van een meerderheidsaandeelhouder $(>50 \%)$ in niet-structuurvennootschappen aanzienlijk groter is dan in structuurvennootschappen, behoudens die met een beperkt regime;

de relatieve frequentic van grootaandeelhouders $(>25 \%)$ in niet-structuurvennootschappen groter is dan in structuurvennootschappen, behoudens die met een beperkt regime; de vrijwillige adoptie van het structuurregime aanzienlijk meer voorkomt bij ondernemingen zonder meerderheidsaandeelhouder $(>50 \%)$ dan bij ondernemingen met zo'n meerderheidsaandeelhouder;

- de vrijwillige adoptie van het structuurregime iets meer voorkomt bij ondernemingen zonder grootaandeelhouder $(>25 \%$ ) dan bij ondernemingen met zo'n grootaandeelhouder.

Deze bevindingen zijn in overeenstemming met do verwachting dat niet-structuurvennootschappen een meer geconcentreerd aandelenbezit kennen (kleinere ondernemingsomvang) dan structuurvennootschappen (grotere ondernemingsomvang). behalve voor het beperkt regime, dat in het alge- meen van tocpassing is op afhankelijke dochters. Voorts valt te verwachten dat het vrijwillige structuurregime minder frequent gekozen zal worden door ondernemingen met een relaticf geconcentreerd aandelenbezit. Die verwachting wordt klaarblijkelijk bewaarheid, vooral ten alnzien van ondernemingen met een meerderheidsaandeelhouder.

Hoe is het nu gesteld met de onathankelijkheid van het Nederlandse ondernemingstoezicht in vergelijking met andere landen? De volgende paragraaf tracht antwoord te geven op deze vraag. Daarbij zal wat de Nederlandse situatie betreft het structuurregime als uitgangspunt worden genomen.

\section{Onafhankelijkheid in vergelijkend perspectief}

Tegen de achtergrond van de in paragraaf 2 beschreven kenmerken van uiteenlopende toezichtsystemen zal nu het Nederlandse structuurregime worden geëvalucerd op het aspect van onafhankelijkheid. Daarbij wordt het eerder gemaakte onderscheid tussen de twee typen onafhankelijkheid aangehouden, namelijk onafhankelijkheid van het ondernemingsbestuur en onafhankelijkheid ten opzichte van de stakeholders.

\section{Onufhankelijkheid van het bestur.}

Een $t w o-t i e r$ structuur biedt in beginsel een grotere mate van onafhankelijkheid dan een one-tier structuur. Er is immers een formele scheiding tussen de organen van bestuur en van toezicht. De Raad van Commissarissen bestaat uitsluitend uit externen, heeft een eigen voorzitter, stelt zijn eigen agenda op. en komt tot zijn eigen conclusies. De commissarissen worden door de aandeelhoudersvergadering afzonderlijk van het bestuur gedechargeerd. De verantwoordelijkheden en aansprakelijkheden van commissarissen verschillen van die van bestuurders.

De mate van onafhankelijkheid in one-tier boards is naar verwachting een functie van het relatieve aantal externe leden, van de eventuele affiliaties van externe leden met ondernemingsbestuurders uit anderen hoofde dan het toezicht, en van de omstandigheid of de voorzitter van de hoard al dan niet dezelfde persoon is als de voorzitter van het managementteam (chief exceutive officer).

Eerder werd reeds aangegeven dat vergroting van de mate van onathankelijkheid van one-tier boards wordt bepleit door allerlei instanties. Gedurende de afgelopen 25 jaar hebben grote Amerikaanse ondernemingen de proportic van onafhankelijke leden in hun boards of directors 
aanzienlijk opgevoerd. Veel ondernemingen beschikken intussen over "supermajority independent boards'. met slechts één of twee interne functionarissen (managers) ${ }^{5}$. Britse ondernemingen zijn er, op aanbeveling van de Cadbury Commissie. massaal toe overgegaan om een scheiding aan te brengen in de vervulling van het voorzitterschap van de board en die van de directic. Bovendien hebben, zowel in de Verenigde Staten als in het Verenigd Koninkrijk, veel hoards speciale commissies in het leven geroepen, die uitsluitend worden bemand door onafhankelijke leden (audit committee, nominating committee, remuneration committee).

De mate van onafhankelijkheid kan overigens in beide structuren worden belemmerd vanwege interlocking directorships (zoals een situatie waarbij persoon $\mathrm{X}$ commissaris is bij onderneming $\mathrm{A}$ en bestuurder bij onderneming $B$, terwijl persoon $Y$ commissaris is bij onderneming $B$ en bestuurder bij onderneming $A$ ), voormalige bezetting van directiefuncties en dergelijke. Voorts dient te worden onderkend dat in het wo-tier systeem de Raad van Commissarissen gewoonlijk vergadert in aanwezigheid van de Ralad van Bestuur. Dat is uiteraard noodzakelijk voor een adequate taakvervulling, maar houdt het gevaar in dat de mate van onafhankelijkheid in de praktijk minder perfect is als de formele scheiding van de organieke structuur zou doen vermoeden.

Uit deze vergelijking komt naar voren dat de verschillen in onathankelijkheid van het ondernemingsbestuur genuanceerd dienen te worden benaderd. Met name in de one-tier landen is men zich in toenemende mate bewust van het belang van dit type onafhankelijkheid.

\section{Onafhankelijkheid ten opzichte van de stakeholders}

Dit type onafhankelijkheid lijkt een specifiek Nederlandse aangelegenheid te zijn. Volgens de Nederlandse wet dient de Raad van

Commissarissen zich bij de vervulling van zijn taak naar het belang van de vennootschap en de met haar verbonden onderneming te richten. Hij fungeert als een college met gezamenlijke verantwoordelijkheid zonder mandaat en onafhankelijk van bij de vennootschappen betrokken deelbelangen. zoals die van aandeelhouders, werknemers, of schuldeisers. Onder het structuurregime wordt deze onafhankelijkheid verder ondersteund door de voorgeschreven benoemingsprocedures. waarbij aandeelhouders en werknemers weliswaar over een aanbevelings- en een bezwaarrecht beschikken, maar niet tot feitelijke benoeming gerechtigd zijn. Dit recht berust bij de Raad van Commissarissen zelf; door coöptatie wordt de benoeming van commissarissen 'uitgetild' boven het niveau van stakeholders-gewijze deelbelangen.

In de Anglo-Amerikaanse context dienen de hoards zich te richten naar het belang van de aandeelhouders ${ }^{6}$. Beloningsvormen in termen van opties van Amerikaanse board-leden, die zeer gangbaar zijn, versterken uiteraard een dergelijke oriëntatie. Deze trend komt overigens steeds sterker ook in continentaal-Europa op.

In Latijns-Europese landen prevaleren eveneens de belangen van aandeelhouders. Aangezien kernaandeelhouders veelal vertegenwoordigd zijn in het toezichthoudend orgaan, wordt dic oriëntatie op het aandeelhoudersbelang daardoor sterk bevorderd. Dit kan evenwel ten koste gaan van de minderheidsaandeelhouders.

Het Duitse systeem van ondernemingstoezicht impliceert dat de belangen van kapitaal en arbeid - van de aandeelhouders en van de werknemers worden geïnternaliseerd in de Aufsichtsrat, hetgeen gemakkelijk kan leiden tot belangentegenstellingen. In feite is er een sterke afhankelijkheid van deze stakeholders, zij het dat die afhankelijkheid per definitie minder eenduidig is dan in de aandeelhouder-georiëntcerde landen.

Uit dit overzicht komt naar voren dat het type onafhankelijkheid van de stakeholders een specifiek Nederlandse aangelegenheid is. In andere landen hebben de toezichthouders zich te richten naar de belangen van de aandeelhouders en. in Duitsland, ook die van de werknemers.

\section{Hoe belangrijk is onathankelijkheid?}

Hicrvoor is aangegeven dat onafhankelijk toezicht (ten opzichte van het ondernemingsbestuur) vrijwel overal ter wereld van groot belang wordt geacht voor een goede corporate governance praktijk. Betekent dit nu ook dat ondernemingen met een onafhankelijk toczicht beter presteren dan andere ondernemingen? Met name in de Verenigde Staten is veel cmpirisch onderzoek verricht naar de relatie tussen board-samenstelling en ondernemingsprestaties. De resultaten vertonen een gemengd beeld. Zo vindt Weisbach (1988) dat bij ondernemingen met relatief veel onafhankelijke bourcl-leden duidelijk strenger wordt opgetreden tegen slecht presterende directievoorzitters dan bij ondernemingen met relatief veel insiders in de hoarl.

Byrd en Hickman ( 1992) laten zien dat ondernemingen met een meerderheid van onafhankelij- 
ke leden in de board een beter rendement bereiken dan ondernemingen zonder zo'n meerderheid. De rendementen worden evenwel negatief beïnvloed indien de fractie van onafhankelijke leden in de board extreem hoog (hoger dan 60\%) wordt. Rediker en Seth (1995) benadrukken de onderlinge substitueerbaarheid van alternatieve disciplineringsmechanismen, bijvoorbeeld tussen de aanwezigheid van grootaandeelhouders en aandelenbezit door de ondernemingsleiding. Ook Agrawal en Knoeber (1996) verrichten empirisch onderzoek naar de samenhang tussen verschillende disciplineringsmechanismen. $\mathrm{Zij}$ vinden een negatief verband tussen ondernemingsprestaties en de fractie externe leden in de board $^{7}$. Klein (1998) betrekt de aanwezigheid van specifieke commissies binnen de board in haar onderzoek. Zij komt tot de slotsom dat de externe leden geen bijdrage leveren aan het ondernemingsresultaat.

Bhagat en Black (1998) stellen, mede op basis van het vele empirische onderzoek van anderen, dat de betekenis van onafhankelijke board-leden voor de ondernemingsprestaties moeilijk is aan te tonen, getuige het volgende citaat (p. 31) 'Then, too, board independence may simply not be very important, on average and over time, compared to other factors that influence corporate performance'.

Gilson en Kraakman (1991, p. 865) merken op dat onafhankelijke toezichthouders misschien niet onafhankelijk genoeg zijn: 'corporate boards need directors who are not merely independent (of management), but who are accountable (to shareholders) as well'. Hiermee leggen ze een verbinding tussen het eerste type onafhankelijkheid (ten opzichte van het bestuur) en het tweede type onafhankelijkheid (ten opzichte van, in dit geval, de aandeelhouders).

Ook in ons land wordt het tweede type onafhankelijkheid door sommigen aan de kaak gesteld $^{8}$. Achter de ruime formulering van het ondernemingsbelang kan men zich immers relatief comfortabel verschansen. Doordat men met alle belangen heeft rekening te houden wordt de verantwoordingsplicht mogelijk diffuus. Als men aan velen verantwoording verschuldigd is, zo kan men stellen, is men het in feite aan niemand.

Dit is niet geheel het geval, al was het alleen al omdat de Raad van Commissarissen telkenjare decharge dient te verkrijgen van de Algemene Vergadering van Aandeelhouders. Ontevreden aandeelhouders kunnen decharge over het door commissarissen uitgeoefende toezicht aan hen onthouden. Het komt niet veel voor dat van dit recht gebruik wordt gemaakt, maar dat is een andere zaak.

Recentelijk is de figuur van de werknemerscommissaris weer in het geding gebracht, onder andere van vakbondszijde en van politieke zijde . De Commissie-Peters heeft aanbevelingen opgesteld om de positie van de kapitaalverschaffers te versterken, vooral door bestaande beperkingen weg te nemen. Min of meer als reactie hierop wordt thans een vergroting van de invloed van werknemers bepleit. In die optiek zou een deel van de Raad van Commissarissen moeten worden benoemd door de werknemers, een deel door de aandeelhouders en de rest via coöptatie (bijvoorbeeld $1 / 3,1 / 3,1 / 3$ ). Een dergelijke opzet benadert ten dele het Duitse systeem, waarover zeer velen die daarmee ervaring hebben opgedaan slecht te spreken zijn. In feite zijn we hiermee terug bij de jaren zestig van de vorige eeuw, toen de Sociaal Economische Raad, nadat de Commissie-Verdam op het punt van het benoemingsrecht verdeeld bleek te zijn, het 'wonder van Den Haag' uit de hoed toverde: coöptatie.

Het is saillant om te zien dat de Sociaal Economische Raad thans opnieuw voor de opgave staat om van zijn wijsheid ten aanzien van dit kennelijk controversiële punt te doen blijken.

\section{Tot slot}

Onafhankelijkheid van het toezicht in ondernemingen staat hoog op de agenda van pleitbezorgers voor een adequate corporate governance praktijk. In internationaal verband richt men het vizier dan met name op onafhankelijkheid ten opzichte van het bestuur. In ons land wordt daar tevens aan toegevoegd onafhankelijkheid van de stakeholders. Corporate governance berust op sleutelbegrippen als integriteit, transparantic en verantwoording. Sommigen zijn van mening dat het systeem van coöptatie onvoldoende prikkelt tot het afleggen van verantwoording aan aandeelhouders. Dit aspect is sinds de rapportage van de Commissie-Peters een steeds indringender onderwerp van publieke discussie geworden.

Onafhankelijkheid van het toezicht ten opzichte van het ondernemingsbestuur wordt vrijwel overal ter wereld bepleit. Empirisch onderzoek ter zake laat evenwel weinig overtuigende bevindingen zien dat zulks ook in alle gevallen tot betere ondernemingsprestaties leidt. De samenhang met andere disciplineringsmechanismen dient in feite steeds in beschouwing te worden genomen.

Dan is er nog het punt van de vermeende aantasting van onafhankelijkheid via kruislingse posities (interlocking directorships), ofwel de vorming van een old boys-netwerk, dat zou uitnodigen tot een consensusmentaliteit en een weinig kritische houding. Alhoewel men uiteraard dient te waken voor verlies aan discipline dient hier evenwel ook rekening te worden gehouden met kwaliteitseisen 
die aan toezichthoudende functies zijn verbonden Naast onathankelijkheid mag ook deskundigheid en betrokkenheid van een commissaris worden verlangd. De cumulatie van deze vereisten brengt mee dat het reservoir van kandidaten walruit voor dit type vertrouwensfunctics kan worden geput een zekere begrenzing kent. Sommigen liggen zo goed in de markt door hun deskundigheid. ervaring en persoonlijkheid - dat het vrijwel ondoenlijk is dat zij hun relatienetwerk met bedrijven, organisaties en personen tot elkaar nimmer kruisende betrekkingen beperken. Sterker, zo'n netwerk kan als zodanig de uitoefening van de adviserende en toezichthoudende taak door een commissaris aan betekenis doen toenemen. Het spreekt vanzelf dat de persoonlijke integriteit van toezichthoudende functionarissen buiten elke twijfel dient te staan. Onalhankelijkheid van het toezicht berust niel alleen op zuiverheid in de formele verhoudingen, maar stellig ook op integriteit en normbesef.

\section{Bijlage}

Aanbevelingen van de Commissie-Peters (1997). warin het aspect onathankelijkheid expliciet of impliciet áa de orde is:

2 De Raad van Commissarissen dient zodanig to zijn samengesteld dal de leden ten opzichte van elkaar en de Raad van Bestuur onafhankelijk en kritisch opereren.

4 In de Raad van Commissarissen dient niet meer dan één voormalig bestuurder van de vennootschap zitting te hebben.

5 Ook commissarissen die worden benoend op basis van een voordrachi vervullen hun taak zonder mandaat van degenen door wie zij zijn voorgedralgen en onathankelijk van bij de onderneming betrokken deelbelangen. Dit betekent dal zij zich net zomin als de overige commissarissen dienen te committeren aan een bepaald deelbolang met voorbijgaan van de andere betrokken belangen.

7 Commissarissen moeten ussentijds aftreden wanneer dit bij onvoldoende functioneren. structurcle onenigheid van inzichten, onverenigbaraheid van belangen of anderszins geboden is.

8 Een commissaris met een tegenstrijdig belang meldt dit terstond aan de voorzitter van de Raad van Commissarissen.

10 Een lid van de Raad van Commissarissen dient niel door hï̈rarchische ondergeschiktheid binnen een groep. door kruisverbanden of door andere verhoudingen met de personen op wie hij toezicht houdt, te worden belemmerd in de onathankelijke uitoefening van zijn toezichthoudende taak.

12 De honorering van een commissaris is niet afhankelijk van de resultaten van de vennootschap. Elke zakelijke relatic met de onderneming word gepubliceerd in de toelichting op de jaarrekening.

13 Elke schijn van belangenverstrengeling tussen onderneming en commissarissen wordt vermeden.

20 Een permanent gedelegeerd commissaris is niet wenselijk.

\section{LITERATUUR}

Agrawal, A. en C.R. Knoeber, (1996), Firm performance and mechanisms to control agency problems between managers and shareholders, Journal of Financial and Quantitative Analysis, 31, pp. 377397

Baysinger, B. en H. Butler, (1985), Corporate governance and the board of directors: performance effects of changes in board composition, Journal of Law, Economics and Organization. 1. pp. 101-124

Bhagat, S. en B. Black, (1998), in: Klaus Hopt, Mark Roe, and Eddy Wymeersch, eds., Corporate governance: the state of the art and emerging research, Oxford University Press.

Boot, A.W.A., (1994), De financiering van het bedriffsleven; tussen structuurregime en financiële sector. Amsterdam University Press, Amsterdam.

Boot, A.W.A., (1999), Corporate governance hoe nu verder? Maandblad voor Accountancy en Bedrifseconomie, 73, pp. 533-544.

Byrd, J.W. en K.A. Hickman, (1992), Do outside directors monitor managers; evidence from tender offer bids, Journal of Financial Economics, 32, pp. 195-221.

Cadbury-committee report. Financial aspects of corporate governance, (1992), Burgess Science Press: UK

Commissie Corporate Governance, (1997), Corporate governance in Nederland: de veertig aanbevelingen, Kluwer, Deventer.

Franks, J.R., C. Mayer en L. Renneboog, (1998), Who disciplines bad management? Working paper CentER, Tilburg University.

Gilson, R.J. en R. Kraakman, (1991), Reinventing the outside director: an agenda for institutional investors, Stanford Law Review, 43, pp. 863-906.

John, K. en L. Senbet, (1998), Corporate governance and board effectiveness, Journal of Banking and Finance, 22, pp. 371-403.

Jong, A. de en P.W. Moerland, (1999), Beheersingsmechanismen in Nederland: substituut of com- 
plement?, Maandblad voor Accountancy en Bedrifseconomie, 73, pp. 499-512.

Klein, A., (1998), Firm performance and board committee structure, Journal of Law and Economics, 41, pp. 275-303.

Moerland, P.W., (1997), Corporate Governance: Theorie en praktik in internationaal perspectief, Financiële en Monetaire Studies, 16(1), WoltersNoordhoff, Groningen.

Monitoring Commissie Corporate Governance, (1998), Corporate governance in Nederland 1998: Bericht van de Monitoring Commissie Corporate Governance en de uitkomsten verricht door het Economisch Instituut Tilburg, verbonden aan de Katholieke Universiteit Brabant, Kluwer, Deventer Monitoring corporate governance in Nederland (in Dutch), (1998), Kluwer, Deventer.

OECD principles on corporate governance, (1999), Directorate for financial, fiscal and enterprise affairs.

Rediker, K.J. en A. Seth, (1995), Boards of directors and substitution effects on alternative governance mechanisms, Strategic Management Journal, 16, pp. 85-99.

Rosenstein, S., en J.G. Wyatt, (1990), Outside directors, board independence and shareholder wealth, Journal of Financial Economics, 26, pp. 175-191.

Rosenstein, S., en J.G. Wyatt, (1997), Inside directors, board effectiveness, and shareholder wealth, Journal of Financial Economics, 44, pp. 229-250.

Setting new standards for corporate governance, (1997), 1997 US survey of institutional investors, Russell Reynolds Associates.

Shleifer, A. en R.W. Vishny, (1997), A survey of corporate governance, The Journal of Finance, 52, pp. 737-783.

Weisbach, M., (1988), Outside directors and CEO turnover, Journal of Financial Economics, 20, pp. 431-460.
4 Volgens het Burgerlijk Wetboek, Boek 2, art. 152, e.v.

5 Vergelijk: Bhagat en Black (1998), p.1

6 Vergelijk: Shleifer en Vishny (1997).

7 Voor een Nederlands onderzoek naar de interdepenties tussen disciplineringsmechanismen zij verwezen naar De Jong en Moerland (1999).

8 Vergelijk: Boot (1994, 1999).

9 D'66 en Groen Links, FNV.

\section{NOTEN}

1 De National Association of Corporate Directors beveelt een 'substantial majority' van onafhankelijke directors aan. Datzelfde doet de Business Roundtable. Het spraakmakende pensioenfonds Calpers stelt dat een 'ideale' board of directors slechts één inside director kent, en wel de chief executive officer. Vergelijk: Bhagat en Black (1998), p.1.

2 Vergelijk: Russell Reynolds Associates 1997 U.S. Survey of institutional investors, p. 3.

3 Behoudens Frankrijk waar ondernemingen mogen kiezen tussen het one-tier en het two-tier systeem. Meer dan 90\% van de ondernemingen kent aldaar overigens een one-tier systeem. 